\title{
Adapting flood management to climate change: comparing policy frames and governance practices in the Low Countries
}

\author{
Ann Crabbé, Mark Wiering and Duncan Liefferink
}

\begin{abstract}
Belgium and the Netherlands together form the Low Countries. Empirical research in Flanders (the Dutch-speaking part of Belgium) and the Netherlands proves that there are substantive differences in the organization of governance processes regarding flood management in response to climate change. This article answers the question of how Flanders and the Netherlands, confronted with universal challenges and dilemmas in the governance of adaptation to climate change - integration versus differentiation (multi-sector versus sector-based governance), the problem of scaling (multilevel governance) and the division of public and private responsibilities (multi-actor governance) - are designing and structuring their approaches. More specifically, we look at how differences in the framing of climate adaptation can explain why organizational practices differ. For this purpose, a distinction is made between diagnostic framing (what is the problem?), prognostic framing (what could be possible solutions?) and action framing (how to act?). By referring to existing policy frames, the article explains recent policy choices on climate change adaptation in flood management.

Ann Crabbé (corresponding author) Faculty of Political and Social Sciences, Research group Society and Environment, University of Antwerp,

Sint-Jacobstraat 2,

2000 Antwerp,

Belgium

E-mail: ann.crabbe@uantwerpen.be

Mark Wiering Duncan Liefferink Nijmegen School of Management, Department of Political Sciences of the Environment, Radboud University Nijmegen, PO Box 9108, 6500 HK Nijmegen, The Netherlands
\end{abstract} Key words | adaptation, Belgium, climate change, flood management, framing, The Netherlands

\section{INTRODUCTION}

Belgium and the Netherlands together form the Low Countries. This can be taken quite literally. Considerable parts of the Low Countries are actually located below sea level. One could imagine that the resemblance of the physical context, e.g. the vulnerability for both sea level rise and increasing discharges of major rivers, leads to major similarities in the way these countries deal with the challenge of adapting to climate change.

With adaptation to climate change we mean 'adjustment in ecological, social, or economic systems in response to actual or expected climatic stimuli and their effects or impacts' (Smit \& Pilifosofa 200I). Hereafter, we refer to adaptation to climate change as 'climate adaptation'. Climate adaptation is commonly seen as a local issue since climate-induced impacts are felt locally (e.g. Wilbanks \& Kates 1999). Accordingly, many of the corresponding responses are found at the local level (Cutter 2003).
Earlier studies on how climate adaptation is understood in European countries report a strong focus on water (e.g. Swart et al. 2009; Tompkins et al. 20I0). In the Low Countries, logically, there is emphasis on the management of floods. Climate change is expected to cause an increase in the occurrence and intensity of flooding risk, local flooding from extreme rainfall, and droughts. In this article we focus on climate adaptation and particularly flood management in Flanders and the Netherlands, which are among the most vulnerable parts of Europe when it comes to increasing flood risk (EEA 2006).

The central research question in this article is: how has adaptation been framed and 'translated' into governance practices in Dutch and Flemish flood management and how has this framing influenced changes in governance organization and practices? Based on earlier extensive research on discursive and institutional change in flood 
management in Flanders and the Netherlands, we illustrate the importance of framing in explaining the capacity of flood management arrangements to adapt to new challenges. In doing so, this article seeks to explain recent policy choices on climate adaptation in flood management.

We are not the first to explore this path. In 2000, Miller broke new ground by analyzing societal responses to the impacts of climate change in terms of different collective frames of meaning related to the issue (Miller 2000). His analysis, however, focused on the process of development and stabilization of frames of meaning in the context of the heated scientific debate on climate change in the USA, rather than on the way these frames subsequently helped in shaping specific policy responses. Juhola et al. (20II) applied Miller's approach to the case of climate adaptation in four European countries: Sweden, Finland, the UK and Italy. Also their focus is on the societal process of developing frames, i.e. giving meaning to climate change. Whereas they frequently refer to the impact of framing on concrete adaptation policies, they do not investigate this impact in detail. Other studies do so, but tend to apply framing theory to single case studies (e.g. The Netherlands: Van den Berg 20I3; Vink et al. 20I3) rather than comparative studies. As far as comparative studies on the governance of climate adaptation are available, on the other hand, these tend to focus on newly created organizational structures (i.e. knowledge institutes, policy or legal structures, etc.; e.g. Swart et al. 2009; Massey \& Huitema 20I3) rather than on the frames of meaning or 'taken-for-granted' conceptualizations (De Boer et al. 2010) underlying these governance structures. With its comparative vantage point, this paper is intended to shed more light on the link between frames and actual policies and, thus, to contribute to both policy understanding and scholarly debate.

\section{THEORY AND METHODS}

\section{Theory}

Variations in adaptation policies across countries may be due to differences in climate effects and the particular policies that are affected. However, the extent and nature of institutionalization can also be seen in light of the varying responses to the fundamental wickedness of climate change as a societal problem. It is a problem dominated by uncertainties, raising questions of individual or collective responsibility and accountability. It necessarily engages a broad range of different stakeholders and while consequences for people are potentially severe, advantages of climate adaptation policies may only become visible in the long run. Because of the wickedness and complexity of the problem, the 'making of meaning' is still very much open to debate. In Hajer's (1995) words, there is not yet a (full) 'discursive closure' to the problem complex.

This is why we focus on framing activities, and why we think theory on collective action and the generation of 'collective action frames' is important (Snow \& Benford r988; Benford \& Snow 2000). Processes of societal and political framing of adaptation to climate change can be considered forms of complexity reduction. They serve to make things comprehensible, tangible and manageable. The concept of framing is derived from the work of the sociologist Erving Goffman (1974), who defines frames as 'schemata of interpretation' that enable individuals 'to locate perceive, identify and label' certain phenomena.

Snow \& Benford (I988), who studied collective action frames of social movements such as environmental and anti-nuclear non-governmental organizations (NGOs), refer to three core framing tasks in collective action: diagnostic, prognostic and motivational framing. Diagnostic framing relates to problem identification and attribution, including 'the source(s) of causality, blame and/or culpable agents' (Benford \& Snow 200o). Prognostic framing involves proposed solutions to problems, or 'at least a plan of attack' (Benford \& Snow 2000), as well as general approaches to carry out the plan. Motivational framing provides a 'call to arms' or rationale for engaging in collective action. For NGOs, for example, this entails mobilizing people to go out on the barricades or to boycott specific products.

We translate these core framing tasks to another world, that is, the realm of policy and governance, because we think that they can also be identified in the policy process. Setting a diagnosis of the problem and creating prognoses for it are important processes of reduction of complexity and discursive closure by politicians or policymakers too. As such they underlie specific choices regarding policy instruments and implementation (De Boer et al. 20Io). 
However, the term motivational framing as conceptualized by Snow and Benford is strongly linked to mobilization strategies of social movements and appears less suitable for the policy arena. Inspired by Goffman, among others, and more directly relevant to the present article, Schön \& Rein (1994) connected the concept of framing to a more reflective approach in policy analysis (see also Donald Schön's earlier work on the reflective practioner, e.g. Schön (I983)). It is important to note that Schön and Rein distinguished two types of policy controversies. In 'normal' policy disagreements, they argued, the fight is over evidencing statements with the 'right' facts and convincing others of the prevalence of certain factual evidence. More fundamental policy controversies, in contrast, tend to be immune to appeals to facts because the very views on what counts as facts can be different. In those controversies, in other words, frames of meaning determine what we see as reality or what we believe to be of value and importance. The wicked issues of climate change and climate adaptation clearly come under the latter type of more fundamental policy controversies. Schön and Rein developed an even broader understanding of frames than Snow and Benford, ranging from rhetorical frames, via policy frames to action frames, that are in turn conceived to be influenced by broader institutional and meta-cultural frames in a country. The categories of policy frames and action frames can be directly related to our purpose. Whereas policy frames, according to Schön and Rein, include diagnostic and prognostic framing activities as in Snow and Benford's conceptualization, the category of action framing refers to rationales for action of any actor involved in the policy process and thus offers a useful alternative for Snow and Benford's strongly NGO related motivational framing.

The wickedness and discursive openness of climate adaptation has its ramifications not only for the framing of the issue, but also for its governance. Since climate change affects a variety of stakeholders in society and many different policy fields, it necessarily asks for an encompassing and integrated policy approach. The added value of our article, as argued in the introduction, is that we explore the link between framing and actual flood management strategies from a comparative perspective. Instead of going into the prescriptive question of which form of governance would be most appropriate for adaptation policies (for a critical discussion, see Keessen et al. (2013) and Wiering et al. (20I5)), we focus here on a descriptive and explanatory approach: to what extent are adaptation policies geared towards multi-actor, multi-sector or multi-level governance, and why?

Generally speaking, we think that the debate on governance is about dealing with processes of societal change. Governance arrangements in west European societies respond to: (1) the emancipation of citizens and processes of individualisation; (2) changes in the scale of societal interactions; and (3) the ongoing differentiation of societal structures and - at the same time - the need for coherence and integration. These evolutions are summarised as respectively the multi-actor, the multi-level, and the multisector trend (Wiering \& Crabbé 2006). Similar dilemmas can be recognized in the governance of climate adaptation.

The reader should be aware that framing and governance of a given issue are, at the end of the day, 'dialectically' or recursively connected: framing has a profound impact on organizational choices, but the organizational setting can also influence framing. Even though, for the sake of constructing the argument, we decided to use the framing of the issue of climate adaptation as the starting point for our analysis, this has to be kept in mind when digesting the following empirical sections.

\section{Methods}

The empirical sections of this paper are based on a comparison of two cases. We explore framing activities regarding adaptation to climate change in the Netherlands and Flanders and investigate how particular forms of framing have affected organizational arrangements around the issue (Flanders, the northern part of Belgium, is considered to be the national level in the cross-case comparison as Belgium has transferred most of the formal competences relevant for climate adaptation to the regional level). We apply a case study approach because it offers a suitable method to take the complexity of the context into account (see e.g. Yin I984).

We applied 'strategic sampling' to select the Netherlands and Flanders (Flyvbjerg 2006). The two cases are similar in general political settings (multiparty democracies) and share specific problems related to climate change (sea level 
rise, coastal defence, discharge of major rivers). We also see differences between both countries with regard to approaches in flood management. Our stance is that these differences cannot be explained only by variation in administrative culture and structure. We expect that the domestic framing of the problem can explain the institutional response to it. Different responses to extreme flooding in the past can illustrate this. For instance, the dramatic framing of the 1953 flooding event in the Netherlands, which killed 1835 people, provoked the ambitious coastal defence system of the Delta Works as well as a strong institutionalization of flood management. The same event in Flanders also led to human casualties, although a considerably lower number, but did not provoke significant institutional change there. The similarities between the Netherlands and Flanders enable us to learn as much as possible on the 'dialectics' of framing and choices in governance of adaptation.

The data stem from two research projects on climate adaptation. One is a research project evaluating if Flemish policy sectors are ready to mainstream climate adaptation measures in their respective policy domains. The research was financed by the Flemish Environment Agency and was carried out in 2011 (Crabbé 20п). The data on the Netherlands stem from a project conducted under the Dutch Knowledge for Climate Change programme (www. knowledgeforclimate.nl; see Termeer et al. 20II). In the present article, we take the opportunity to compare the results of both projects, which ran in the same period with roughly similar project aims. In both projects, document analysis, supported by in-depth interviews, was used for gathering empirical data. The contents of national policy documents on water management in general and adaptation to climate change in particular were examined in order to identify the framing and organization of adaptation. Both in the Netherlands and Flanders, more than twenty interviews were held with societal stakeholders and national/regional civil servants. In the Dutch research, in total 22 interviews were held. These included 10 interviews with representatives of the Delta Programme, three interviews with water experts from Deltares and the Waterdienst, five interviews with decentral governments (province, water boards, municipalities), two with the Ministry, one interview with an agricultural interest group and one with a transboundary organization. In the Flemish research, 10 face-to-face interviews and 10 interviews by telephone were held with public servants from the Flemish government (experts in water policy, climate adaptation, spatial planning, etc.) and with representatives of market players (e.g. consultancy firms) and civil society (NGOs, sector federations, etc.). The in-depth interviews were based on open-ended questionnaires and aimed to retrieve views and experiences of the respondents on the issues of framing of climate adaptation and organizational responses to it. The interviews played a clarifying role, in addition to the document analysis.

\section{FRAMING OF CLIMATE ADAPTATION}

First, we describe the framing and organization of climate adaptation in the Netherlands and Flanders. Then, we offer our analytical reflections on both.

\section{Framing in the Netherlands}

\section{Diagnostic framing}

Climate change potentially affects large parts of Dutch society, including the water system, nature, agriculture, human health, transport and infrastructure, energy and ICT mainframes (Ligtvoet et al. 2012). In 2012, the Netherlands Environmental Assessment Agency reported that the average temperature had increased by $1.7^{\circ} \mathrm{C}$ during the last century, which is about twice as high as the global average. Yearly precipitation had increased by about $20 \%$ and periods of heavy rainfall had become much more frequent. Future consequences are nevertheless uncertain (see Figure 1), which seriously complicates adaptation to possible future climate change (Ligtvoet et al. 2012).

Although the Netherlands is probably one of the best protected deltas in the world, the Dutch have a tendency to think in terms of possible (flood) apocalypse (Hajer 1995). Because of a long history of catastrophic floods and rebuilding of flood defence infrastructures as well as land reclamation and maintenance of polders, the Dutch developed an ambivalent relationship with water: it is their worst enemy as well as their greatest friend.

For these reasons, climate change is very easily framed in terms of the threat of flooding. This is evidenced, for 


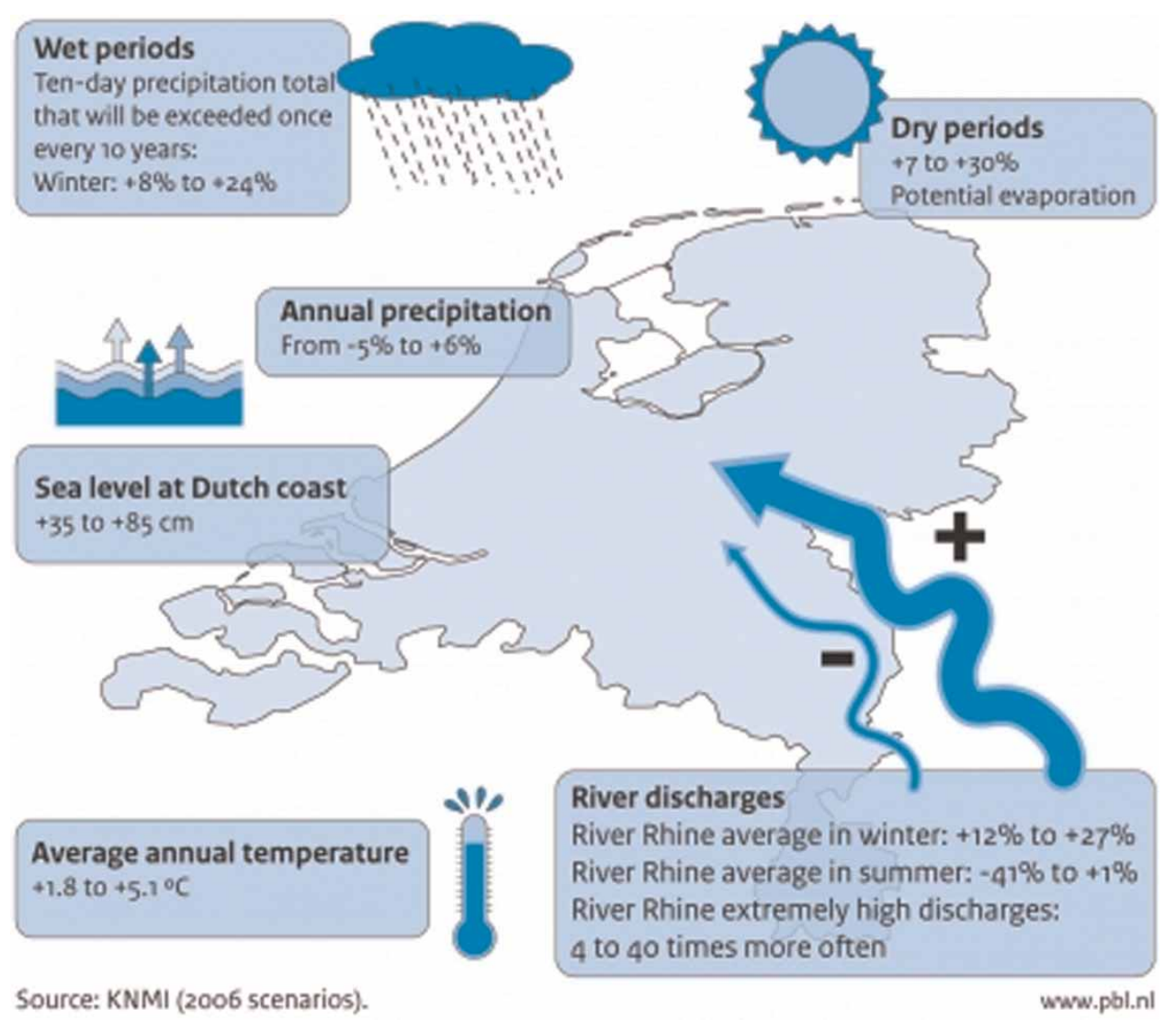

Figure 1 | Possible climate changes for the 1990-2100 period according to KNMI'06 scenarios (Ligtvoet et al. 2012).

example, by the communication of the influential Second Delta Committee (www.deltacommissie.com/film; Verduijn et al. 2012; Vink et al. 2013). The Committee, established by the Dutch government in 2007 (see below), stresses the importance of the 1953 sea storm surge event and reduces the complexity of the issue to the (more comprehensible and more manageable) matter of a 'safe delta'. The core diagnostic frame is that of vulnerability and resilience of the hydrological system (Van Os et al. 2012; Van den Berg 20I3). Secondary issues of concern include drought in the country's lower sandy areas and fresh water supply.

\section{Prognostic framing}

Over the past decade, the Netherlands has put more emphasis on climate adaptation than on climate mitigation and the two issues are mostly separated. In the preparation of a national adaptation plan, water safety has not always been the core frame. As Van den Berg (20I3) described, a gradual shift occurred in the Dutch approach to climate adaptation from a more integrated, ecologically and spatially relevant perspective - with accompanying ambitions - to a more 'down to earth' (perhaps better rephrased to 'down to water'), 'realistic', 'evidence based', engineering approach focusing on water topics, such as water safety, drought, fresh water supply and water supply for economic functions. Van den Berg elegantly summarized this shift by distinguishing three storylines in Dutch adaptation strategies. First, a storyline of 'water accommodation' stemmed from the discourses of 'living with water' and 'room for the river' prevalent in the 1990s and 2000s. At that time, integrated water management and a system-based approach were considered important as is evidenced by the report on Water Policy for the 21st century (Ministry of Transport, Public Works and Water Management 200o). Second, the 'climate proof' storyline developed along with upcoming discussions on climate adaptation strategies around 2004-2006. This approach of climate proofing addressed a broader spectrum 
of water management, spatial planning, economic infrastructure as well as nature conservation to prepare for climate change effects in the long run. Finally, a 'safe delta' storyline emerged from 2008, following the recommendations of the Delta Committee and their successful implementation, following a narrower interpretation of climate change effects primarily in terms of water and risk. Reflecting this shift from the 'accommodating' and 'climate proofing' frames to that of a 'safe delta', the message became: don't wait for a flood disaster to happen but rather act pro-actively and adapt the system with the help of the expertise of the water management sector and a clear demarcation of budgets and rules (www.deltacommissie.com/film; Verduijn et al. 20I2). Thus, the Delta Programme managed to secure a considerable budget for the coming decades in the so-called Delta Fund. Adaptation programmes in fact reach out to the end of the 21st century, which fits the problem of climate change.

The almost exclusive focus on the water sector in the current framing of climate change and adaptation can be related not only to the dominance of water management in the Netherlands, but also to other societal and political factors. For instance, the financial crisis caused a step back from overly ambitious long-term plans, whereas the current right wing, neo-liberal government tries to avoid speaking of climate policy altogether. This leads to an emphasis in policy documents on general, collective 'water safety' instead of preparing for climate change, as well as promotion of the Dutch 'top sector' water as a potential export product.

\section{Action framing}

The, mostly internal, political-governmental struggle of how to frame climate adaptation eventually led to a dominant position of water management and a weaker position of those interests that strived for a more integrated ecosystem-related approach including environmental and nature values (Biesbroek et al. 20I3). The focus on the hydrological system, most notably water safety and fresh water supply, should be warranted by the special institutions of the Delta Programme (Delta Act, Delta Fund, Delta Sub-programmes and Delta Commissioner). The core concepts of the concrete courses of action, so-called 'key Delta decisions', still have to be established, but a higher level of safety standards and mainstreaming climate adaptation measures with other important decisions concerning spatial infrastructure and economic development will be part of it. A possible important institutional change may derive from an increased emphasis on shared responsibility regarding flood risks. It leads to the concept of multi-layered safety, with more room for involving (local) spatial planning and (regional) safety institutions (veiligheidsregio's). A large part of the Delta fund will be spent on renewal of the flood risk safety programme (Hoogwaterbeschermingsprogramma), more specifically on the setting of new flood risks safety standards and the related maintenance and enforcement of sea and river dikes. Most of the policy measures related to fresh water are about connecting the availability of water to the expected demand and the balance of fresh and salt water. Measures in other policy domains are limited and mainly related to flood proofing of housing and infrastructure. Exceptions to the strict water-relatedness in the Netherlands are the climate proofing of cities, offering room for other urban, climate-related problems such as health and heat stress, and area-specific integrated programmes in both cities and rural areas. For example, the city of Rotterdam has an ambitious overarching programme on urban climate change adaptation (www.rotterdamclimateinitiative.nl). The Waalweelde project seeks synergy between challenges of water safety, regional economy, housing, nature, tourism, energy and climate mitigation along riverbanks in the east of the country (www. waalweelde.nl).

\section{Framing in Flanders}

\section{Diagnostic framing}

Researchers of the Catholic University of Louvain and the Belgian Royal Meteorology Institute developed three climate scenarios: a wet, a moderate and a dry scenario (Willems et al. 20I0). As their Dutch equivalents, these scenarios indicate that by 2100 temperatures will rise in Flanders, winter precipitation level will increase, summer rain levels will decrease and more thunder storms in summer are to be expected. The sea level at the Belgian coast will rise by $60-90 \mathrm{~cm}$, with a worst case scenario of $200 \mathrm{~cm}$ (Flemish Government 20I3). In order to find out the exact impact of 
climate change in their domains, various policy sectors have ordered studies to analyze their additional vulnerability (e.g. Gobin et al. 2008; Waeterloos 2010).

Water managers expect to see three major consequences, specifically for the water sector. First, climate change will lead to an increased flood risk, both from the sea and rivers and from sewers. Second, water quality is likely to deteriorate, amongst others because of the rise of water temperature, salinization and increased concentrations of polluting substances (due to evaporation and sediment transports). Third, longer periods of drought can negatively affect (drinking) water availability (Flemish Government 20I3).

\section{Prognostic framing}

In Flanders, mitigation and adaptation are considered reverse sides of the same medal. 'No matter how hard we try to reduce greenhouse gas (GHG) emissions, climate change will affect us and we need to prepare for it. The other way round, the more the GHG emissions are reduced, the easier to prepare for the consequences of climate change' (Flemish Government 20r3). In Flanders, political support for adaptation measures significantly depends on the extent to which measures contribute to both mitigation and adaptation goals. Flemish policy-makers want to see creative and cost-efficient policy-making, leading to winwin solutions.

Having said that, adaptation as such is rather low on the priority list as there are many other problems that are perceived to be more acute or more important, e.g. the financial crisis. In her policy note of 2009, the Flemish Minister for the Environment stated: 'First the consequences of the economic crisis must be tackled' (Schauvliege 2009). Postponing measures for long term threats is not exceptional, in particular in the sector of water management. Flooding events can sometimes serve as a 'window of opportunity'. This can be illustrated with the 1976 dike breach that put the communality of Ruisbroek under water for more than 2 weeks. This event was an eye-opener because it launched the frame that the government did not sufficiently protect the people from flooding (because of lack of dike maintenance) as it was distracted by consecutive major state reforms.
Are the consequences of climate change seen mainly as a risk or as an opportunity? With regard to the sea level rise, the focus is on the importance of protecting coastal areas against the threat of flooding. In view of the economic importance of the coastal area, the implementation of the 2011 Master Plan on Coastal Safety is politically nor socially disputed (www.kustveiligheid.be). At the same time, working on coastal safety is perceived as an opportunity to create new developments for nature, economy, tourism, recreation, shipping and sustainable energy. An eye-catching example is the Flanders Bays 2100 initiative. In the first instance, this initiative was a broadly communicated vision for the Belgian coast, developed by Flemish but internationally active dredging companies (www.vlaamsebaaien.com). It propagated a redevelopment from a narrow coast defended by hard dikes to a broad and soft coast with dunes, sandbanks and islands, offering new opportunities for economic, touristic and nature developments.

\section{Action framing}

The time horizon for mitigation and adaptation measures is different. As GHG emissions need to be reduced in the short term, mitigation measures in the Climate Policy Plan (Flemish Government 20I3) focus on 2020 and look forward to 2050. Because the (international) pressure is lower, climate adaptation policies can incrementally work on the realization of a future vision. As is usual in other Western countries, including the Netherlands, Flanders uses the year 2100 as the time horizon for adaptation, but the Flemish Climate Policy Plan focuses on measures to be implemented in the timeframe 2013-2020.

The Climate Policy Plan is focused on initiatives by the Flemish government. Still a lot of work needs to be done with regard to creating awareness of shared responsibility between public and private players. Governments tend to draw responsibility towards themselves and need time to learn how initiatives of other stakeholders can be integrated, supported or mainstreamed. On the other hand, individuals are rather keen on letting governments take full responsibility. With Flanders Bays 2100, Flemish dredging companies showed ambition to bring private partners' adaptation goals on the agenda. In response to that, the Flemish government initiated its own Flanders Bays project in which the 
development of an integrated vision for the future of the Belgian coast was put on the agenda (www.maritiemetoegang. be/vlaamse-baaien).

The Flemish government introduced the 'climate reflex' (Flemish Government 2013). This reflex is about (a) screening of existing and new policies of all policy domains against climate change scenarios, thus contributing to reducing Flanders' vulnerability, and (b) adapting these existing or new policies to the threats of climate change. The development of new adaptation measures is not a primary goal.

In deciding which measures should be taken, cost efficiency is an important argument. The cost of adaptation should be lower than the cost of potential damage. In the updated Sigma plan, aiming to protect the basin of the Sea Scheldt, for instance, measures are only selected when their cost-effectiveness is demonstrated, in contrast to the Netherlands, where measures are selected primarily on their capacity to contribute to a fixed safety standard, no matter what the cost-effectiveness is.

Ecosystem services, finally, entail all goods and services that ecosystems can deliver to society, such as natural protection against flooding, natural water sanitation, recreation in nature, etc. An ecosystem services approach requires investments in healthy and resilient ecosystems with functional and well-balanced biodiversity and prefers low-technology, low-maintenance, energy-efficient and quite simple measures. It often lays other claims on land use, moreover, which incites cooperation with spatial planners, e.g. when water managers request more room for the river. As an integrated water policy approach is considered a prerequisite for sustainable development of water systems in Flanders as well as in view of costefficiency, Flemish water managers show a rather strong preference to propagate ecosystem services for tackling adaptation challenges.

\section{First comparison of framing in the Netherlands and Flanders}

Table 1 summarizes and compares the framing of climate adaptation in the Netherlands and Flanders.

\section{GOVERNANCE STRUCTURE FOR CLIMATE ADAPTATION}

\section{Governance arrangements in the Netherlands}

The Netherlands has a long history of managing water, but adaptation to climate change is a relatively new challenge. The interdepartmental National Programme for Spatial

Table 1 Comparing policy frames on climate change adaptation in the Netherlands and Flanders

\begin{tabular}{|c|c|c|}
\hline & The Netherlands & Flanders \\
\hline $\begin{array}{c}\text { Diagnostic } \\
\text { framing }\end{array}$ & $\begin{array}{l}\text { Climate change poses threats to the low lying delta. Sea } \\
\text { level rise and increasing discharges of the major rivers } \\
\text { are problematic. In addition to that, drought in the lower } \\
\text { sandy areas and fresh water supply are a matter of } \\
\text { concern }\end{array}$ & $\begin{array}{l}\text { Based on scenario studies everybody agrees upon, } \\
\text { practically every policy domain has commissioned its own } \\
\text { vulnerability assessment. The water sector faces three } \\
\text { major consequences: increased flood risk, deteriorating } \\
\text { water quality and longer periods of drought }\end{array}$ \\
\hline $\begin{array}{c}\text { Prognostic } \\
\text { framing }\end{array}$ & $\begin{array}{l}\text { Climate adaptation is separated from climate mitigation; } \\
\text { adaptation is considered more urgent. The core frame is } \\
\text { that of the 'safe delta', set by the Delta Committee in } \\
\text { 2008. It entails a pro-active approach to avoid flooding } \\
\text { with the help of the knowledge of the water management } \\
\text { sector }\end{array}$ & $\begin{array}{l}\text { Adaptation and mitigation are considered two sides of the } \\
\text { same coin. But other problems are considered more } \\
\text { urgent, e.g. the economic crisis. Safety is on the agenda, } \\
\text { see the priority in implementing the coastal safety plan } \\
\text { between } 2011 \text { and } 2015\end{array}$ \\
\hline $\begin{array}{l}\text { Action } \\
\text { framing }\end{array}$ & $\begin{array}{l}\text { Government should focus on the hydrological system and } \\
\text { create a new level of safety. The concept of multi-layered } \\
\text { safety requires more room for shared responsibility } \\
\text { regarding flood risks, e.g. the involvement of spatial } \\
\text { planning and institutions dealing with safety }\end{array}$ & $\begin{array}{l}\text { Adaptation and mitigation are seen as related. There is a } \\
\text { strong preference for low-technology, low-maintenance, } \\
\text { energy-efficient and quite simple measures, framed as } \\
\text { contributing to integrated water management and } \\
\text { ecosystem services. Measures explicitly need to be } \\
\text { effective, efficient, flexible, robust, no-regret and } \\
\text { multifunctional }\end{array}$ \\
\hline
\end{tabular}


Adaptation to Climate Change, published in 2006 (Adaptatieprogramma Ruimte en Klimaat, ARK; see Van Os et al. 20I2; Biesbroek et al. 20I3), was chaired by the (former) Ministry of Housing, Spatial Planning and Environment (VROM) and included three more Ministries: Transport, Public Works and Water Management (VWS), Agriculture, Nature and Food Quality, and Economic Affairs. Building upon the ARK, the Dutch National Adaptation Strategy (NAS) contained a broad vision for adaptation in the Netherlands and distinguished four themes: safety, living environment, biodiversity and (general) environment (Ministry of VROM 2007; Biesbroek et al. 20I3).

However, the Dutch Cabinet wanted the effects of climate change on water safety to be investigated separately. It therefore installed a special State Commission, the Second Delta Committee. Its predecessor, the Delta Committee, had been established after the storm surge disaster of 1953. The Second Delta Committee was established simultaneously with the ARK and NAS processes, but is now coordinated by the Ministry of VWS alone (Biesbroek et al. 20I3). The Committee rapidly developed into the key institution in Dutch adaptation policy. As described above, this marked a shift of frame from a multi-faceted problem in need of an integrated approach, to a strongly water-dominated problem in need of focused institutions and policies (Van den Berg 2013).

\section{Multi-level governance}

As a decentralized unitary state, the Netherlands has three generic administrative levels: national government, provinces and municipalities. At the national level, after the merger of the Ministries of VROM and VWS in 2010, the Ministry of Infrastructure \& Environment (I\&E) is responsible for the management of the main water infrastructure, e.g. the larger waters (e.g. North Sea, Wadden Sea, Lake IJssel) and river estuaries, including the major dams and dikes. Operational water management at this level is carried out by the national agency Rijkswaterstaat.

The regional water authorities (also called water boards) are responsible for both quantity and quality management of all other water bodies. For this purpose, they raise their own taxes. In recent years, the water boards have also cofinanced parts of the main dike infrastructure (Havekes \&
Van Rijswick 20I0), thus further strengthening their role in Dutch water management. With the powerful regional water authorities, Dutch water management can be characterized as functionally decentralized.

At the regional level, two more layers are involved. Provinces formally supervise the regional water boards. Apart from that, they are in charge of integrated spatial planning within their territories. Municipalities usually have no tasks directly relating to the general management of floods and droughts, but they manage drainage and sewer systems as well as groundwater levels in rural areas. Thus, they are responsible for the urban management of pluvial water problems.

Next to the existing structure of water authorities, the Second Delta Committee triggered a series of new institutional arrangements around the issue of water safety. The Committee itself was installed in 2007 and chaired by the former Minister for Agriculture, Cees Veerman. It formulated recommendations for the long term strategy of flood protection and freshwater management (Veerman 2008; Verduijn et al. 20I2). Remarkably, it was not installed in the aftermath of a huge disaster, but rather '(...) to avoid one' (Verduijn et al. 2012). The Delta, although coordinated by the Ministry of I\&E, strongly emphasizes collaboration with regional and local actors. The policies are specified in the National Water Plan, which is frequently updated. The legal foundation for the Delta Programme and the Delta Committee was laid in 2011 with the Delta Act (van der Grijp et al. 20I2).

\section{Multi-actor governance}

It is striking that Dutch policies for climate adaptation have mostly revolved around new institutions starting with the word 'Delta'. The Delta Act regulates the planning, timelines and budget for the Delta institutions with an important role for the Ministry of I\&E. The funding of the Delta Programme will be secured by the Delta Fund, which is administered and safeguarded by the Finance Minister, although final responsibility for the expenditures is, again, with the Ministry of I\&E. The Delta Fund cannot be used for other purposes, as it is anchored in the Delta Act 'without having to compete with other social goals' (van der Gijp et al. 2012). The Delta Commissioner is a governmental 
authority appointed for seven years. His tasks are also anchored in the Delta Act (www.deltacommissaris.nl/ english).

The Delta Commissioner must ensure participation of other stakeholders and there are provisions made to this end in the Delta Programme. Besides, there is a specific knowledge programme, Knowledge for Climate (Kennis voor Klimaat; see Veraart et al. 20I4), that has designated areas of key importance, so-called 'hot spots', where adaptation problems must be resolved, for example Main Port Schiphol, the region of Rotterdam and the Wadden Sea.

Despite the seemingly open design of the Delta Programme, the Dutch approach to climate adaptation is strongly state-oriented. The general public is hardly involved and market (businesses) and civil society are awaiting the 'core Delta decisions'. As a result, climate change and adaptation no longer reaches headlines in Dutch media and has ceased to play a major role in Dutch politics in favour of, for instance, the battle against the financial crisis.

\section{Multi-sector governance}

In the foregoing, it has been repeatedly emphasized that the Dutch chose an adaptation path that focuses heavily on a sector-based approach. The complexity of climate change in general is reduced to the lesser complexity of water management. The earlier multi-sector approach, understood as 'climate proofing' through spatial measures (Van den Berg 20I3) and through alignment of and synergy between different sectoral policies, has been largely abandoned, at least for the moment. This allowed the Dutch to secure a Delta Programme with an impressive budget of many billions for the coming decades in the midst of an economic crisis. The focused approach helped to keep the Delta Programme out of day-to-day politics without having to compete with other social goals. This is at least partly due to the trust people have in the techno-sector of water management.

\section{Governance arrangements in Flanders}

The Flemish Climate Policy Plan 2013-2020 has an overarching part and two separate but equally treated sub-plans: the Flemish mitigation plan and the Flemish adaptation plan. The Flemish adaptation plan is written in a coproduction between all policy domains concerned, with the Flemish Ministry for the Environment as coordinator and chair of the writing team and each of the policy sectors contributing a section of their own, e.g. on nature and biodiversity, public health, spatial planning, agriculture, water, international development. The Flemish adaptation plan does not come with extra resources. Instead, the Flemish government has instructed the relevant policy administrations to take full policy and financial responsibility to conduct necessary research, take new initiatives, intensify existing initiatives and evaluate their contribution to climate adaptation (Flemish Government 20I3). So, the responsibility to develop climate resilient policies is put entirely with the policy sectors.

In contrast to other sections written by specific policy departments, the section on water is written by the Interdepartmental Co-ordination Commission on Integrated Water Policy (hereafter: CIW), assembling representatives of various policy domains, such as environment, mobility and public works, and spatial planning. The CIW plays a crucial role in supporting multi-sector, multi-level and multi-actor governance. It was not installed specifically for the development of climate adaptation policy in Flanders. It builds upon a process, initiated in the 1990s, to attune and 'integrate' the policies of the numerous water managing instances in Flanders.

\section{Multi-sector governance}

Flanders has a multitude of water managers with different stakes and other viewpoints, and in many cases they openly disagree. However, with the installation of the CIW, a platform was created in which discussions can be settled. Water managers participate in the CIW on a voluntary basis, but it is acknowledged that the CIW is the place to be to influence decision-making on water management. The Decree on Integrated Water Policy of 18 July 2003 anchors the idea that all government institutions relevant for water management should work in the spirit of an integrated, river basin based approach in which water systems are sustainably managed and ecosystem services are promoted.

Water managers, assembled in the CIW, decided not to develop new policy initiatives for climate adaptation. In their opinion, they would already contribute to adaptation by implementing the European Floods Directive (FD) and the Water Framework Directive (WFD). The CIW proposes 
a variety of measures, necessary to reduce climate change impact: sustainable management of water resources, balancing ground water extraction, optimal water quality management, protection against flooding, preventing floods and improving the hydro-morphology of rivers (Flemish Government 20I3). Flanders particularly distinguishes itself from other European regions by actively integrating the implementation of the FD and WFD. This will lead to one integrated plan covering both directives in 2015 (Kellens et al. 20I3).

Water managers see the importance of creating win-win situations for more than one policy sector. This generates more political and societal support, which increases chances to receive the necessary resources. With the actualization of the Sigma Plan, Waterways \& Sea Canal NV for example linked its flood risk management for the Sea Scheldt with the ecological restoration of the river, important for the implementation of the Birds and Habitats Directive (Broekx et al. 20II).

In Flanders, measures to reduce flood risks will only be selected if they prove cost-effective. Therefore, Flemish water managers prefer to make economic analyses, allowing more objective underpinning of project selection and enabling efficient public spending (Strubbe et al. 2005). The Department of Mobility and Public Works was pioneer in developing the economic approach by using social costbenefit analysis for the navigable water ways. Later, the Flemish Environment Agency ordered its own economic analysis while preparing Flood Risk Management Plans for the unnavigable water courses.

Flanders has a young tradition of active cooperation with spatial planning on flood risk management. Already in 2003, i.e. much earlier than in the Netherlands, the Decree on Integrated Water Policy introduced the mandatory use of a strong policy instrument preventing flood risks: the water test. Through this test, the competent authority, deciding upon a permit plan or programme, estimates the impact thereof on the water system. The outcome of the water test is then included into the permit, plan or programme. With the budget allocated for implementation of the water test, the spatial planning department appointed personnel for the CIW secretariat. These staff actively prepares CIW decisions in cooperation with the water managers. They write policy notes and convince their own administration to change its ways, in the advantage of water stakes. This is a quite unique cooperation, helpful to take away the discursive and institutional barriers between the two sectors.

\section{Multi-level governance}

Water management in Flanders takes place at three levels of government: the Flemish government, provinces and municipalities. In the distribution of competences, a distinction is made between navigable waterways and non-navigable watercourses. Navigable waterways in Flanders belong to the competence of the Department of Mobility and Public Works and are in practice managed by three separate governmental agencies which operate with a relatively high degree of independence. The management of the non-navigable watercourses is divided over the Flemish Environment Agency (VMM), the provinces, the municipalities and so-called Polders and Wateringues.

Considering the multitude of actors involved in the management of the non-navigable watercourses, a reclassification of those watercourses is now on the agenda (Flemish Government 20II). After various information and consultation rounds, many municipalities have decided to transfer their competence to the province. On 11 October 2013, the Flemish government principally agreed on a draft version of new legislation on the unnavigable watercourses. The CIW plays a crucial role in preparing for this legislative initiative.

\section{Multi-actor governance}

Most Flemish people expect the government to safeguard them from the impacts of climate change. The Flemish government, however, increasingly communicates about shared responsibility and the necessity of citizens contributing to flood risk prevention. For example, the VMM published a brochure on adaptive building and adaptive renovation, stimulating house owners and their architects to take into account potential flood risks.

The Flanders Bays 2100 initiative of the dredging companies gained a lot of public attention. Because of its thought-provoking character, the Flemish Minister for Public Works instructed her administration to evaluate the idea, in the light of the Flemish coast safety plan. In November 2013, Minister Crevits announced, based on cost-benefit 
analysis, that sand islands are not an option on the west coast, but they could be relevant at the east side of Zeebrugge (De Standaard 2014). Explorative discussions with the Dutch administration are being started up, including the set-up of scientific research, to find out if cross-border sand islands are realistic.

Flanders does not have a large-scale active participation programme regarding flood risks. The FD obliges the European countries to make their flood risk management plans available and accessible to the general public. In Flanders, this obligation to passive communication is anchored in the Decree Integrated Water Policy. On a small scale, workshops on different aspects of flood risk management planning are or will be organized. The participants to these workshops are mainly professionals. Communication with citizens is limited, due to the technical nature of the message (Kellens et al. 2013).

\section{Changes in governance arrangements in the Netherlands and Flanders}

Table 2 gives an overview of governance arrangements around climate adaptation in the Netherlands and Flanders.

\section{DISCUSSION AND CONCLUSIONS}

Drawing together in one sentence what we have found so far, we may conclude that governance arrangements for climate adaptation in the Netherlands strongly focus on water-related problems with a key role played by state actors, whereas in Flanders arrangements appear to be more open to both other policy sectors and other types of actors. Even though the differences are only a matter of degree, and water as well as the state remain important in Flanders too, one may assert that Flanders tends to a slightly more multi-sector and multi-actor approach than the Netherlands. As regards the multi-level dimension of governance arrangements around adaptation, we observed that both in the Netherlands and Flanders, besides the crucial coordinating role of the central level, an increasing amount of operational tasks is allocated to the regional level, i.e. to the water boards and the provinces, respectively.

We will now have a closer look at these differences and try to link them to differences in the framing of climate adaptation between the Netherlands and Flanders.

In the Netherlands, policies on climate mitigation and adaptation were strongly separated from the beginning, with adaptation dominating over mitigation especially over

Table 2 | Comparing governance arrangements for climate change adaptation in the Netherlands and Flanders

\begin{tabular}{|c|c|c|}
\hline & The Netherlands & Flanders \\
\hline $\begin{array}{l}\text { Multi-sector } \\
\text { governance }\end{array}$ & $\begin{array}{l}\text { Mitigation and adaptation are strongly separated } \\
\text { Action is taken under the umbrella of the Delta } \\
\text { Programme which is emphasizing water management } \\
\text { issues. Historically, Dutch water policy is characterized } \\
\text { by sectoral functional governance } \\
\text { Substantial earmarked resources have been made available } \\
\text { for the Delta Programme }\end{array}$ & $\begin{array}{l}\text { Mitigation and adaptation plans are part of one Climate } \\
\text { Policy Plan } \\
\text { The adaptation plan yields no separate resources; policy } \\
\text { actions fall under the policy and financial responsibility } \\
\text { of the policy sectors involved } \\
\text { In water management: } \\
\text { - the coordination commission CIW plays a crucial } \\
\text { positive role } \\
\text { - actions are taken under the umbrella of WFD/FD rather } \\
\text { than that of adaptation } \\
\text { win-win situations for various policy sectors are a } \\
\text { prerequisite for policy action }\end{array}$ \\
\hline $\begin{array}{l}\text { Multi-level } \\
\text { governance }\end{array}$ & $\begin{array}{l}\text { There are four layers of government, including the } \\
\text { functional layer of the water boards which play a key } \\
\text { role in regional water management } \\
\text { There is a tendency to (further) decentralize from national } \\
\text { to regional level }\end{array}$ & $\begin{array}{l}\text { Flemish water management is characterized by a historic } \\
\text { fragmentation of competences: } \\
\text { - at the central level, CIW plays a crucial, positive role } \\
\text { - for efficiency reasons, competences are currently } \\
\text { shifting from local water managers to provinces }\end{array}$ \\
\hline $\begin{array}{l}\text { Multi-actor } \\
\text { governance }\end{array}$ & $\begin{array}{l}\text { Dutch water management, including the Delta Programme, } \\
\text { is dominated by the state } \\
\text { There is no large-scale societal or market-based } \\
\text { participation }\end{array}$ & $\begin{array}{l}\text { Flemish water management is dominated by the state. } \\
\text { There are no large-scale active participation } \\
\text { programmes, but market players publicly influence } \\
\text { government's agenda (e.g. Flanders Bays 2100) }\end{array}$ \\
\hline
\end{tabular}


the last decade. In Flanders, in contrast, adaptation has long remained in the shadow of debates on mitigation. Currently, an attempt is made in Flanders to connect both sides of the coin, at least on paper, in the form of the Climate Policy Plan 2013-2020. However, when it comes to formulating policies, also in Flanders mitigation and adaptation follow different tracks.

In the Netherlands, adaptation policy is predominantly about water safety. Considering the geography of the country, this does not come as a total surprise, but compared to the broader view still propagated in the 2007 NAS (Biesbroek et al. 20I3; Van den Berg 20I3), the rapid and almost complete exclusion from the national debate of the possible impact of climate change on, for instance, health or biodiversity is striking. This narrowing-down of focus went hand in hand with an increasingly dominant role given to the established water institutions in developing adaptation policies. Significant milestones in this process included the installation of the Second Delta Committee in 2007, and the shift of key coordination tasks regarding climate adaptation from the Environment Ministry (VROM) to that responsible for Public Works (VWS, but note that the two merged in 2010 into the current Ministry of I\&E) - and in its wake the national water authority Rijkswaterstaat and the functional layer of the regional water boards. In addition to that, the 2011 Delta Act provided for an earmarked budget for water safety. Although a discourse of integrated water management had in fact slowly gained ground in the Netherlands in the 1990s, not least in relation to implementing the WFD (Liefferink et al. 20II), climate adaptation has as yet been hardly affected by this discourse.

In Flanders, the other part of the Low Countries, water issues are obviously considered a key element of climate adaptation policies too. Here, however, the development of policies relating to water management and climate adaptation has been much more directly linked to the implementation of the WFD as well as the FD. This was to a large extent due to the influential role of the interdepartmental CIW. The discourse on integrated water policy stimulated coordination with adjacent policy fields such as spatial planning, public works, etc. The idea of shared responsibility thus obtained firmer footing in this area than in the Netherlands. This led to more attention for cross-sectoral win-win situations and cost-effectiveness. Private players started to challenge the Flemish government to develop a long-term vision on climate adaptation, as illustrated by the Flanders Bays 2100 initiative launched by the dredging companies. Whereas in the Netherlands, in other words, water safety in relation to climate adaptation was established and institutionalized almost as a new policy field with its own earmarked budget, Flemish adaptation policy was much more embedded in the existing institutional structure of integrated water policy. In the Flemish case, however, this went without an earmarked budget, putting a strain on the room for new initiatives.

At the most fundamental level, the differences between the Netherlands and Flanders can be related to the sense of urgency expressed in the diagnostic framing of climate change. In the Netherlands, the rising sea level and increasing peaks in the discharge of the major rivers was almost immediately associated with numerous, almost mythical flooding disasters from the past and thus regarded as a major safety threat. In Flanders, the situation was framed less dramatically, not least because a much smaller part of the territory is actually lying below sea level than is the case for the Netherlands. This means that problems associated with climate change in Flanders - local flood risks, deterioration of water quality, salinization, etc. - are no doubt taken seriously but do not have a comparably mythical status as in the Netherlands.

From this point of view, and moving to the levels of prognostic and action framing, it can hardly be a surprise that climate change in the Netherlands was presented as little less than a new 'battle against the water', legitimizing the planning of expensive pro-active measures, requiring an exclusive budget and almost necessarily led by the state - a true defence policy. In institutional terms, this way of framing the issue smoothly fed it into the existing, strongly sectorized water infrastructure. In Flanders, in contrast, climate adaptation had to compete with other pressing problems that are politically equally high or even higher on the agenda. Besides, the only recently installed, multi-level and multisector CIW came in as the obvious starting point for a more integrated approach to climate adaptation. Given the framing as a shared problem of many policy sectors, the resulting policies were less strongly dominated by water managers.

The multi-level aspect of climate governance arrangements has so far remained outside the discussion, but 
largely confirms the picture just sketched. In the Netherlands, the rapid incapsulation of climate adaptation by the strong, existing world of water institutions met with a generic trend towards decentralization advocated by recent Dutch Cabinets and also affecting the water boards. Consequently, and without much discussion, the regional water boards have started to play an increasing role also in the prevention of flooding and the debate about climate adaptation (Havekes \& Van Rijswick 20I0). In Flemish water management, in contrast, some responsibilities have shifted from the local level to the level of the provinces, mainly for efficiency reasons. This strengthening of the provincial role is quite remarkable as the general framing is that, in the future, Flanders only needs a Flemish regional and a local administrative level, not a provincial level anymore (Flemish Government 20II). Our interpretation is that the provinces managed to attract an additional competence because Flanders lacks strong functional authorities for (local) water management, comparable to the Dutch water boards. Another explanation might be that strengthening the provincial role might be the result of a strong political lobby, aiming at the 'survival' of the provincial level. The seeming concentration of competences at the level between national and local authorities in both the Netherlands and Flanders must hence be seen as a contingency, as it is coming from different directions and fuelled by different dynamics, whereas in the Netherlands the now strongly institutionalized field of climate adaptation as a matter of course followed the multi-level ups and downs of its 'parent' area, i.e. water management, the multi-level movement of Flemish adaptation policy appears to be the result of a pragmatic, efficiency-motivated but also a political choice in favour of the provincial level.

We have repeatedly highlighted the 'selective framing' of climate adaptation as a predominantly water related issue in the Netherlands. Recently, this selectivity was criticized by the Dutch Court of Auditors (Algemene Rekenkamer 2012). From the point of view of efficiency and appropriateness, indeed, one might wonder what the best approach is in creating institutions for adaptation to climate change. In the Dutch case, the span of policies is limited, but considering the large earmarked budget and the powerful Delta institutions, among other things, the chosen path turns out as highly effective and 'robust'. The Flemish approach is relatively shared, integrated and encompassing, but the resources for actual measures are very limited. The difference between the Netherlands and Flanders in this respect appears to reflect a more universal dilemma between a firm, sectorbased but seemingly 'one-sided' focus on the one hand and a multi-sector but possibly loose and fragmented approach on the other. In further research, it would be interesting to see how other countries deal with this dilemma in the face of the complex problem of climate adaptation.

In this article, we have described differences in the organization of policies regarding adaptation to climate change in the Netherlands and Flanders and have linked those differences to the underlying societal framing of issues of climate change and adaptation. We have tried to demonstrate, for instance, that the dominant position of the traditional water sector in Dutch adaptation policy is not a coincidence: it can be linked to a deeply felt, historically rooted sense of urgency when it comes to issues of water safety. At the same time, there can be little doubt that this particular form of institutionalization of adaptation policy in the Netherlands, expressed for instance by the key position of the Delta Committee, in turn contributes to the path-dependent continuation of a strongly water-focused framing of the consequences of climate change in the Netherlands. The same is true for Flanders, where the way in which the CIW addresses the issue confirms and reproduces a more integrated framing.

Although in this paper we have, for analytical reasons, separated the framing of climate adaptations and the governance practices around the issue, the two are intimately and recursively linked. To the best of our knowledge, this article is the first to present a comparative case study in which the relevance of framing for understanding variations in institutional responses is illustrated. By focusing on framing, it adds a crucial dimension to the reports in which national adaptation strategies are assessed on their institutional aspects only.

\section{ACKNOWLEDGEMENTS}

The empirical information in this paper stems from two research projects on climate adaptation. The Flemish research was financed by the State of the Environment Reporting team of the Flemish Environment Agency. The research that underpinned the Dutch case study was supported by the 
Consortium 'Governance of Climate Adaptation' of the Dutch Knowledge for Climate Programme. The authors would like to express their gratitude towards the commissioning instances for making their work possible.

\section{$\overline{\text { REFERENCES }}$}

Algemene Rekenkamer 2012 Aanpassing aan klimaatverandering: strategie en beleid. Sdu, Den Haag.

Benford, R. D. \& Snow, D. A. 2000 Framing processes and social movements: An overview and assessment. Annu. Rev. Sociol. 26, 611-639.

Biesbroek, G. R., Termeer, C. J., Klostermann, J. E. \& Kabat, P. 2013 Analytical lenses on barriers in the governance of climate change adaptation. Mitig. Adapt. Strateg. Glob. Change 19, 1-22.

Broekx, S., Smets, S., Liekens, I., Bulckaen, D. \& De Nocker, L. 2oIr Designing a long-term flood risk management plan for the Scheldt estuary using a risk-based approach. Nat. Hazard. 57, 245-266.

Crabbé, A. 20II Klaar voor wat komt? Over de invoering van klimaatadaptatiebeleid in Vlaanderen. Research report of research commissioned by the Flemish Environment Agency. VMM, Aalst.

Cutter, S. L. 2003 The vulnerability of science and the science of vulnerability. Ann. Assoc. Am. Geog. 93, 1-12.

De Boer, J., Wardekker, J. A. \& Van der Sluijs, J. P. 20ıо Framebased guide to situated decision-making on climate change. Glob. Environ. Change 20, 502-510.

De Standaard 20I4 Zandeilanden in Noordzee kunnen enkel voor oostkust. Newspaper article of 28 November 2013. Available from: www.standaard.be/cnt/dmf20131126_00857847. Last accessed: 5 February 2014.

EEA 2006 Vulnerability and Adaptation to Climate Change in Europe. Report of the European Environment Agency. EEA, Copenhagen.

Flemish Government 20II White book internal state reform. Policy document, agreed upon by the Flemish Government on 8 April 2011. Available from (in Dutch): http://binnenland. vlaanderen.be/interne-staatshervorming/totstandkomingwitboek. Last accessed: 18 February 2014.

Flemish Government 20I3 Flemish climate policy plan 2013-2020. Policy document, agreed upon by the Flemish Government on 28 June 2013. Available from (in Dutch): www.lne.be/ themas/klimaatverandering/klimaattips/klimaattips/watdoet-de-vlaamse-overheid/vlaams-klimaatbeleidsplan. Last accessed: 5 February 2014.

Flyvbjerg, B. 2006 Five misunderstandings about case-study research. Qual. Inq. 12, 219-245.

Gobin, A., Van De Vreken, Ph., Van Orshoven, J., Keulemans, W., Geers, R., Diels, J., Gulinck, H., Hermy, M., Raes, D., Boon,
W., Muys, B. \& Mathijs, E. 2008 Adaptatiemogelijkheden van de Vlaamse landbouw aan klimaatverandering. Research report of research commissioned by the department Agriculture and Fishery (section Monitoring \& Study) of the Flemish Government. Klimaatpark Arenberg, Leuven.

Goffman, E. 1974 Frame Analysis: An Essay on the Organization of Experience. Harvard University Press, Cambridge, Massachusetts.

Hajer, M. A. 1995 The Politics of Environmental Discourse: Ecological Modernization and the Policy Process. Clarendon Press, Oxford.

Havekes, H. J. \& Van Rijswick, H. F. M. W. 20Io Waterrecht in Nederland. Kluwer, Deventer.

Juhola, S., Keskitalo, E. C. H. \& Westerhoff, L. 20II Understanding the framings of climate change adaptation across multiple scales of governance in Europe. Environ. Pol. 20, 445-463.

Keessen, A. M., Hamer, J. M., Van Rijswick, H. F. \& Wiering, M. 2013 The concept of resilience from a normative perspective: examples from Dutch adaptation strategies. Ecol. Soc. 18, 45.

Kellens, W., Vanneuville, W., Verfaillie, E., Meire, E., Deckers, P. \& De Maeyer, P. 2013 Flood risk management in Flanders: past developments and future challenges. Water Resour. Manage. 27, 3585-3606.

Liefferink, D., Wiering, M. \& Uitenboogaart, Y. 20п The EU Water Framework Directive: a multi-dimensional analysis of implementation and domestic impact. Land Use Pol. 28, 712-722.

Ligtvoet, W., Franken, R., Pieterse, N., Van Gerwen, O. J., Vonk, M., Van Bree, L., van den Born, G. J., Knoop, J., Kragt, F., Paardekooper, S., Kunseler, E., van Minnen, J., Pols, L., Reudink, M., Ruijs, A. \& Tennekes, J. 2012 Climate Adaptation in the Dutch Delta: Strategic Options for a Climate-Proof Development of The Netherlands. Report of the Dutch Environmental Assessment Agency. PBL, The Hague.

Massey, E. \& Huitema, D. 2013 The emergence of climate change adaptation as a policy field: the case of England. Region. Environ. Change 13, 341-352.

Miller, C. A. 2000 The dynamics of framing environmental values and policy: four models of societal processes. Environ. Values 9, 211-233.

Ministry of Transport, Public Works and Water Management 2000 A Different Approach to Water: Water Management Policy in the 21st Century. Ministry of Transport, Public Works and Water Management, The Hague.

Ministry of VROM 2007 Maak ruimte voor het klimaat! Nationale adaptatiestrategie - de beleidsnotitie. Ministerie voor Volkshuisvesting, Ruimtelijke Ordening en Milieubeheer, Ministerie voor Verkeer en Waterstaat, Ministerie voor Landbouw, Natuur en Voedselkwaliteit, Ministerie voor Economische Zaken, Interprovinciaal Overleg, Vereniging van Nederlandse Gemeenten en Unie van Waterschappen, The Hague.

Schauvliege, J. 2009 Policy note environment and nature 20092014. To be consulted (in Dutch) as Stuk 193 (2009-2010), 
nr. 1 of the Flemish Parliament. Available from: http://docs. vlaamsparlement.be/docs/stukken/2009-2010/g193-1.pdf. Last accessed: 4 February 2014.

Schön, D. A. 1983 The Reflective Practitioner: How Professionals Think in Action. Basic Books, New York.

Schön, D. A. \& Rein, M. 1994 Frame Reflection: Toward the Resolution of Intractable Policy Controversies. Basic Books, New York.

Smit, B. \& Pilifosofa, O. 200I Adaptation to climate change in the context of sustainable development and equity. In: Climate Change 2001: Impacts, Adaptation, and Vulnerability. Contribution of Working Group II to the Third Assessment Report of the Intergovernmental Panel on Climate (J. J. McCarty, O. F. Canzani, N. A. Learn, D. J. Dokken \& K. S. White, eds). Cambridge University Press, Cambridge, pp. 877-913.

Snow, D. A. \& Benford, R. D. 1988 Ideology, frame resonance, and participant mobilization. Int. Soc. Move. Res. 1, 197-217.

Strubbe, J., Mostaert, F. \& Maeghe, K. 2005 Flood management in Flanders with special focus on navigable waterways. In: Integrated flood management: experiences with the implementation and day to day management. Report prepared for the high-level meeting 26 May 2005, Nijmegen, The Netherlands, pp. 1-14.

Swart, R. J., Biesbroek, G. R., Binnerup, S., Carter, T. R., Cowan, C., Henrichs, T., Loquen, S., Mela, H., Morecroft, M., Reese, M. \& Rey, D. 2009 Europe Adapts to Climate Change: Comparing National Adaptation Strategies. Partnership for European Environmental Research (PEER), Helsinki.

Termeer, C., Dewulf, A., van Rijswick, H., van Buuren, A., Huitema, D., Meijerink, S., Rayner, T. \& Wiering, M. 2orr The regional governance of climate adaptation: a framework for developing legitimate, effective, and resilient governance arrangements. Clim. Law 2, 159-179.

Tompkins, E. L., Adger, W. N., Boyd, E., Nicholson-Cole, S., Weatherhead, K. \& Arnell, N. 2oIo Observed adaptation to climate change: UK evidence of transition to a well-adapting society. Glob. Environ. Change 20, 627-635.

Van den Berg, M. 2013 Translating the global climate change discourse to the local: an analysis of Dutch storylines on adaptation. In: Water Governance, Policy and Knowledge Transfer: International Studies on Contextual Water Management (C. de Boer, J. Vinke-de Kruijf, G. Ozerol \& H. T. A. Bressers, eds). Routledge, London, pp. 207-223.

van der Grijp, N. M., Bergsma, E. \& Gupta, J. 2012 The Dutch focus: a Delta Act for climate adaptation. In: Climate Law in EU Member States: Towards National Legislation for Climate Protection (M. Peeters, M. Stallworthy \& J. de
Cendra de Larragan, eds). Edward Elgar, Cheltenham/ Northampton, UK, pp. 312-328.

Van Os, V., Dieperink, C. \& Wiering, M. 2012 Go with the flow? On the development of transboundary policy of climate change adaptation in the Rhine basin. Position paper theme Governance of Climate Adaptation, Knowledge for Climate, Deliverable 5.2.1.

Veerman, C. 2008 Samen werken met water. Een land dat leeft, bouwt aan zijn toekomst. Advisory report of the Delta Commission. Delta Commission, The Hague. Available from: www.deltacommissaris.nl/english. Last accessed: 24 February 2014.

Veraart, J. A., van Nieuwaal, K., Driessen, P. \& Kabat, P. 2014 From climate research to climate compatible development: experiences and progress in the Netherlands. Reg. Environ. Change 14, 851-863.

Verduijn, S. H., Meijerink, S. V. \& Leroy, P. 2012 How the second Delta Committee set the agenda for climate adaptation policy: A Dutch case study on framing strategies for policy change. Water Altern. 5, 469-484.

Vink, M. J., Boezeman, D., Dewulf, A. \& Termeer, C. J. 2013 Changing climate, changing frames: Dutch water policy frame developments in the context of a rise and fall of attention to climate change. Environ. Sci. Pol. 30, 90-101.

Waeterloos, E. 2010 Ontwikkelingssamenwerking en de aanpassing aan klimaatverandering. Aanbevelingen voor de Vlaamse samenwerking met partnerlanden. Research report of the Centre of Expertise on Foreign Affairs. Steunpunt Buitenlands Beleid, Universiteit Antwerpen, Antwerpen.

Wiering, M. \& Crabbé, A. 2006 The institutional dynamics of Water Management in the Low Countries. In: Institutional Dynamics in Environmental Governance (B. Arts \& P. Leroy, eds). Springer, Dordrecht, pp. 93-114.

Wiering, M. A., van Rijswick, H. M. F. W., Green, C., Priest, S. \& Keessen, A. M. 2015 The rationales of resilience in English and Dutch flood risk policies. J. Water Clim. Change 6 (1), 38-54.

Wilbanks, T. J. \& Kates, R. W. 1999 Global change in local places: How scale matters. Clim. Change 43, 601-628.

Willems, P., Baguis, P., Ntegeka, V. \& Roulin, E. 2010 Climate change impact on hydrological extremes along rivers and urban drainage systems in Belgium. Final research report of the CCI-HYDR project. Belgian Science Policy, Brussels. Available from: www.kuleuven.be/hydr/cci/ reports/CCI-HYDR_FinalReport.pdf. Last accessed: 5 February 2014.

Yin, R. K. 1984 Case Study Research: Design and Methods. Sage, Newbury Park, California. 